\title{
Synthesis of a Ni Complex Chelated by a [2.2]Paracyclophane- Functionalized Diimine Ligand and Its Catalytic Activity for Olefin Oligomerization
}

\author{
Daisuke Takeuchi ${ }^{1,2, *}$, Yoshi-aki Tojo ${ }^{1}$ and Kohtaro Osakada ${ }^{1,3, *(D)}$ \\ 1 Laboratory for Chemistry and Life Science, Tokyo Institute of Technology, 4259 Nagatsuta, Midori-ku, \\ Yokohama 226-8503, Japan; tojo.yoshiaki.ma@m-chemical.co.jp \\ 2 Department of Frontier Materials Chemistry, Faculty of Science and Technology, Hirosaki University, \\ 3 Bunkyo-cho, Hirosaki-shi, Aomori 036-8561, Japan \\ 3 National Institute of Advanced Industrial Science and Technology (AIST), Tsukuba Central 5, 1-1-1 Higashi, \\ Tsukuba, Ibaraki 305-8565, Japan \\ * Correspondence: dtakeuch@hirosaki-u.ac.jp (D.T.); kosakada@res.titech.ac.jp or osakada-k@aist.go.jp (K.O.)
}

Citation: Takeuchi, D.; Tojo, Y.-a.; Osakada, K. Synthesis of a Ni Complex Chelated by a

[2.2]Paracyclophane-Functionalized Diimine Ligand and Its Catalytic Activity for Olefin Oligomerization. Molecules 2021, 26, 2719. https:// doi.org/10.3390/molecules26092719

Academic Editor: Michal Szostak

Received: 15 April 2021

Accepted: 3 May 2021

Published: 5 May 2021

Publisher's Note: MDPI stays neutral with regard to jurisdictional claims in published maps and institutional affiliations.

Copyright: ( $\odot 2021$ by the authors Licensee MDPI, Basel, Switzerland. This article is an open access article distributed under the terms and conditions of the Creative Commons Attribution (CC BY) license (https:// creativecommons.org/licenses/by/ $4.0 /)$.

\begin{abstract}
A diimine ligand having two [2.2]paracyclophanyl substituents at the $\mathrm{N}$ atoms (L1) was prepared from the reaction of amino[2.2]paracyclophane with acenaphtenequinone. The ligand reacts with $\mathrm{NiBr}_{2}$ (dme) (dme: 1,2-dimethoxyethane) to form the dibromonickel complex with $(R, R)$ and $(S, S)$ configuration, $\mathrm{NiBr}_{2}(\mathbf{L 1})$. The structure of the complex was confirmed by $\mathrm{X}$-ray crystallography. $\mathrm{NiBr}_{2}$ (L1) catalyzes oligomerization of ethylene in the presence of methylaluminoxane (MAO) co-catalyst at $10-50{ }^{\circ} \mathrm{C}$ to form a mixture of 1- and 2-butenes after $3 \mathrm{~h}$. The reactions for $6 \mathrm{~h}$ and $8 \mathrm{~h}$ at $25{ }^{\circ} \mathrm{C}$ causes further increase of 2-butene formed via isomerization of 1-butene and formation of hexenes. Reaction of 1-hexene catalyzed by $\mathrm{NiBr}_{2}(\mathbf{L 1})-\mathrm{MAO}$ produces 2-hexene via isomerization and C12 and C18 hydrocarbons via oligomerization. Consumption of 1-hexene of the reaction obeys first-order kinetics. The kinetic parameters were obtained to be $\Delta G^{\ddagger}=93.6 \mathrm{~kJ} \mathrm{~mol}^{-1}$, $\Delta H^{\ddagger}=63.0 \mathrm{~kJ} \mathrm{~mol}^{-1}$, and $\Delta S^{\ddagger}=-112 \mathrm{~J} \mathrm{~mol}^{-1} \mathrm{deg}^{-1}$. $\mathrm{NiBr}_{2}(\mathbf{L 1})$ catalyzes co-dimerization of ethylene and 1-hexene to form $\mathrm{C} 8$ hydrocarbons with higher rate and selectivity than the tetramerization of ethylene.
\end{abstract}

Keywords: oligomerization; olefin; nickel; catalysts; $N$-ligand

\section{Introduction}

The oligomerization of olefins catalyzed by transition metal complexes has attracted attention, as shown by many review articles on this topic over the last decades [1-16] as well as recent original reports [17-19]. It is related to the industrial production of unsaturated hydrocarbon materials. The mechanistic studies are of interest from the viewpoint of catalytic and organometallic chemistry. Various complexes of early and late transition metals are employed as the catalyst for the oligomerization. Transition metal complexes were reported to promote cross-dimerization of two alkynes and of alkyne with vinyl compounds to form enynes and dienes, respectively [20-24]. The cross-dimerization of two vinyl compounds has been focused on hydrovinylation of styrene and of olefins containing polar fnctional groups [25-35]. $\alpha, \omega$-Dienes undergo transition metal-catalyzed intramolecular hydrovinylation, which provides a convenient route to the cycloolefins [36-39]. On the other hand, intermolecular cross-dimerization of two hydrocarbon alkenes is rare. Hessen reported that a constrained geometry complex (CGC)-type Ti complex catalyzed crosstrimerization of ethylene with 1-octene to form C12 products [40].

$\mathrm{Ni}$ and $\mathrm{Pd}$ complexes with diimine ligands having bulky $\mathrm{N}$-aryl substituents were found to catalyze high-mass polymerization of ethylene and 1-olefins as well as copolymerization of ethylene with acrylates [41]. The complexes with 2,6-disubstituted aryl groups at the coordinating nitrogens, $\mathbf{1 a - 1 f}$, catalyze ethylene polymerization. Complexes $\mathbf{1 g}$ 
and $1 \mathrm{~h}$ with 4-substituted aryl groups at the nitrogen atoms catalyze oligomerization of ethylene to form $\alpha$-olefins with Schultz-Flory distribution $[42,43]$. Subsequent studies using $\mathrm{Ni}$ and $\mathrm{Pd}$ complexes with strically bulky diimine ligands, $\mathbf{1} \mathbf{i}-\mathbf{1} \mathbf{p}$, as the catalysts revealed the polymerization and co-polymerization of olefins with high productivity and selectivity [44-56].

Occurrence of polymerization or oligomerization of ethylene depending on the substituents of the diimine ligand is rationalized by the insertion- $\beta$-hydrogen elimination mechanism, as shown in Scheme 1. The growing polymer having an alkyl-nickel bond undergoes $\beta$-hydrogen elimination of vinyl group-terminated oligomer to form a hydride(olefin)nickel(II) species (A).

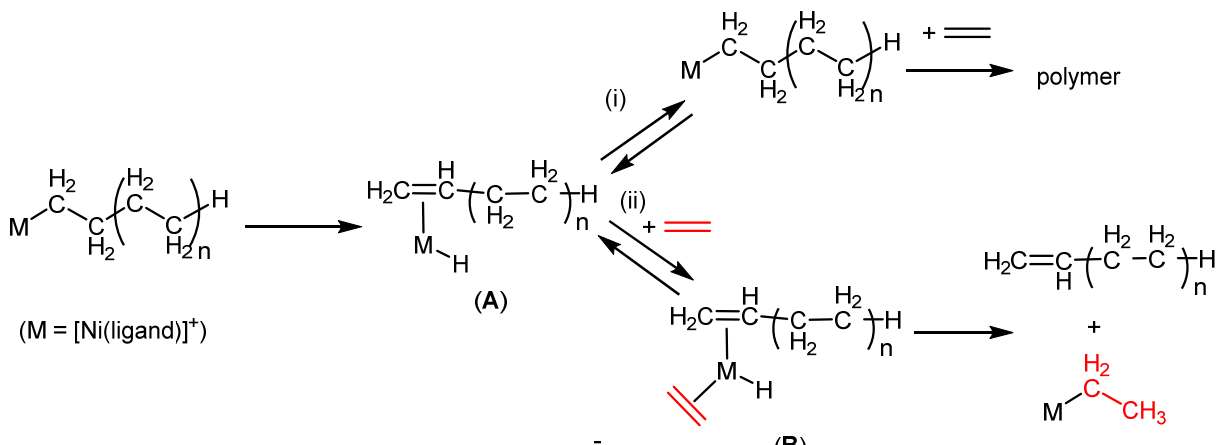

(B)

Scheme 1. Polymerization vs. oligomerization. (A,B) denote intermediates of the reactions.

Intermediate (A) with the ligand having 2,6-disubstituted $N$-aryl groups prefers reinsertion of the vinyl group into the $\mathrm{Ni}-\mathrm{H}$ bond, and resumes the polymer growth (path (i)). $\mathrm{Ni}$ center of intermediate (A) having the diimine ligand with 4-substituted $N$-aryl groups is sterically less crowded, and undergoes associative coorindation of an ethylene monomer at the apical coordination site of square-planar $\mathrm{Ni}$ (II) center, forming intermediate (B) (path (ii)). The reaction is followed by elimination of the oligomer having a vinyl end group and insertion of ethylene into the $\mathrm{H}-\mathrm{Ni}$ bond. Further insertion of ethylene molecules into the $\mathrm{Ni}-\mathrm{C}$ bond provides new oligomer molecules. In this study, we synthesized the $\mathrm{Ni}$ complex with a diimine ligand having [2.2]paracyclophanyl substituents at the $N$-positions. The complex is expected to show new catalytic properties because of the sterically bulky $\mathrm{N}$-cycloparaphenyl groups of the ligand. It catalyzes olefin oligomerization, and ethylene1-hexene co-dimerization, in particular. Here, we report synthesis and structure of the new Ni-diimine complexes as well as its catalysis.

\section{Results and Discussion}

\subsection{Preparation and Structure of Ni Complexes}

Mono-substituted [2.2]paracyclophane has a double-decker structure with a chiral center in the molecule. The transition metal complexes with the paracyclophane-containing nitrogen ligand, such as a Ti-Salen complex [57] and $\mathrm{Au}$ and Rh complexes with Nheterocyclic carbene (NHC) ligands [58-60], were employed as the catalyst for stereoselective reactions. We conducted condensation of acenaphtenequinone with two molar equivalents of amino[2.2]paracyclophane with expecting formation of a diimine ligand having two [2.2]paracyclophanyl substituents. The reaction in refluxing $\mathrm{EtOH}-\mathrm{AcOH}$ proceeds smoothly to form the ligand, according to Equation (1). Both racemic and optically active amino[2.2]paracyclophanes were used in the ligand synthesis. 


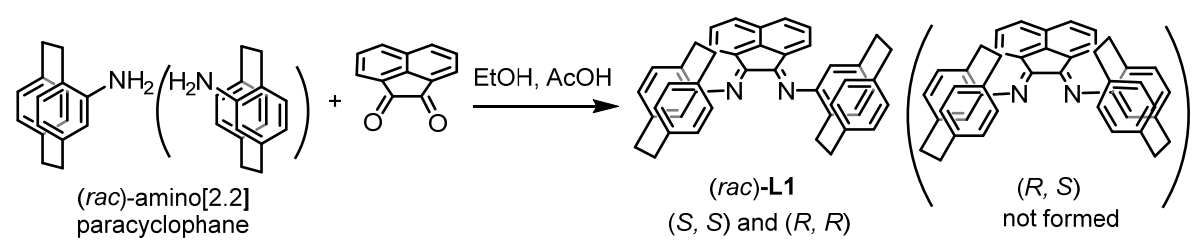

Figure 1a shows the ${ }^{1} \mathrm{H}$ NMR spectra of the ligand $\mathbf{L 1}$, obtained from the racemic (upper) and optically active (lower) amino[2.2]paracyclophanes, respectively. The characteristic aromatic hydrogen signals near the imine group are observed at the same positions. Total spectra of the ligand from the racemic and optically active starting materials are also identical. It suggests that the ligand from a racemic mixture has $(R, R)$ or $(S, S)$ configuration. The ligand having a meso structure with $(R, S)$ or $(S, R)$ configuration is not contained in the product. Figure $1 \mathrm{~b}$ shows results of FAB-MAS measurement of L1. The parent peak at $m / z=593$ corresponds to [M-H] ${ }^{+}$of $\mathbf{L} 1$. These spectroscopic data as well as the results of elemental analysis clearly indicate the formation of ligand L1 in a pure form. Thus, condensation of acenaphtenequinone with racemic amino[2.2]paracyclophane forms L1 diastereoselectively. We used the ligand obtained from racemic amino[2.2]paracyclophane for prepartion of the catalysts of this study.

(a)

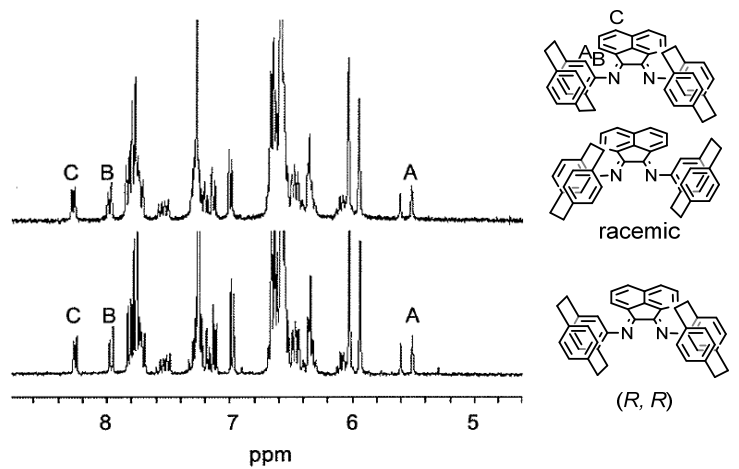

(b)

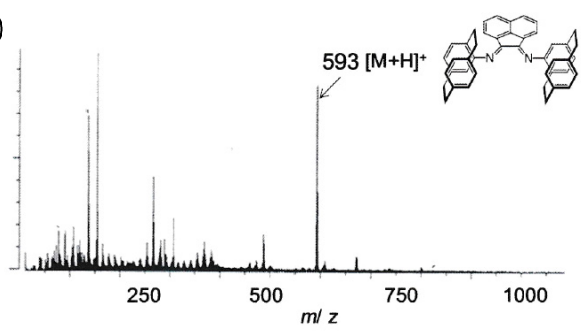

Figure 1. (a) ${ }^{1} \mathrm{H}$ NMR spectra (aromatic hydrogen region) of ligand $\mathbf{L 1}$ obtained from racemic amino[2.2] paracyclophane (upper) and from the optically amino[2.2]paracyclophane (lower). (b) FABMS spectrum of racemic L1 obtained by using 2-nitrobenzyl alcohol as the matrix.

The above ${ }^{1} \mathrm{H}$ NMR spectra of $\mathbf{L 1}$ in Figure 1a contains the signals with a more number than that expected from the molecular structure. It is attributed to the presence of conformational isomers of the compounds in the solution. Figure 2a depicts two isomers due to $E$ and $Z$ geometry about the $\mathrm{C}=\mathrm{N}$ bond, while Figure $2 \mathrm{~b}$ shows possible isomers by rotation of the C-N bond between the [2.2]paracyclophanyl group and the imine group. Sterically crowded structure of the molecule renders interconversion of the isomers difficult even in the solution. Figure $2 \mathrm{c}$ shows the ${ }^{1} \mathrm{H}$ NMR spectra at high temperatures. The signals are broadened above $90^{\circ} \mathrm{C}$, but do not undergo coalescence, which suggests that the interconversion among the conformational isomers is slower than the NMR time scale. 
(a)

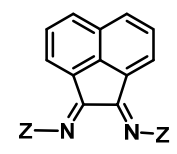

(b)

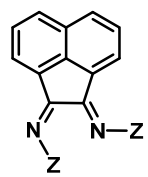

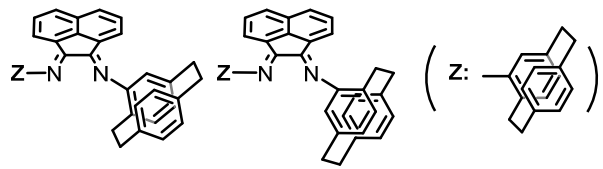

(c)

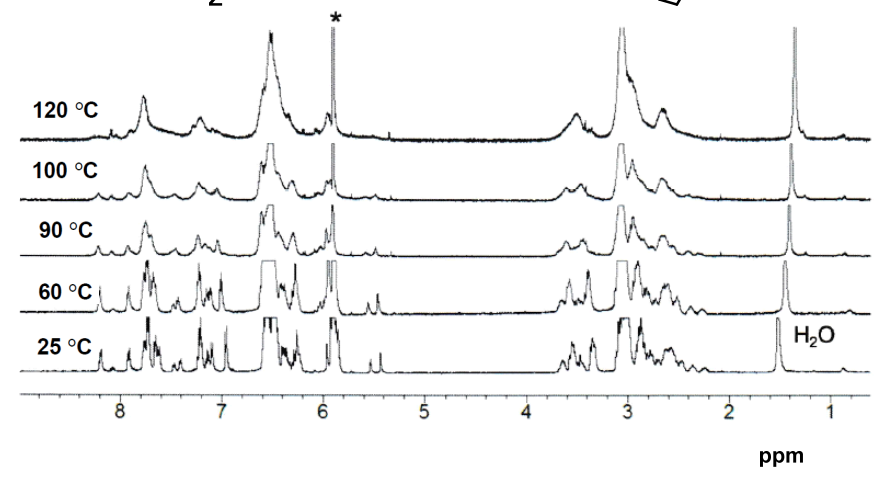

Figure 2. (a,b) Possible conformational isomers of L1. (c) Temperature dependent ${ }^{1} \mathrm{H}$ NMR spectra of $\mathbf{L} 1$ at $25-120^{\circ} \mathrm{C}$.

Ligand $\mathbf{L 1}$ reacts with $\mathrm{NiBr}_{2}(\mathrm{dme})$ (dme $=1,2$-dimethoxyethane) at room temperature to form the complex formulated as $\mathrm{NiBr}_{2}(\mathbf{L} 1)$, as shown in Equation (2). A direct reaction of $\mathrm{NiBr}_{2}$ with 2,5-dimethylaniline and acetonaphtequinone produces $\mathrm{Ni}$ compex with a ligand having 2,5-dimethylphenyl substituents at the imine nitrogen, $\mathrm{NiBr}_{2}(\mathbf{L} 2)$, as shown in Equation (3). Ligand L2 also has 2,5-disubstituted aryl groups at the imine nitrogens, similar to L1, but is sterically much less bulky than L1. Catalytic activity of the complex is compared with that of $\mathrm{NiBr}_{2}(\mathbf{L} \mathbf{1})$, having the sterically more crowded ligand.

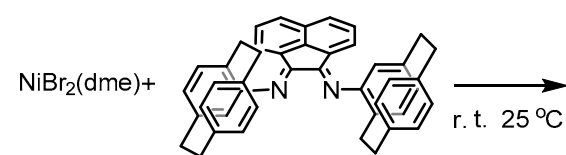

L1

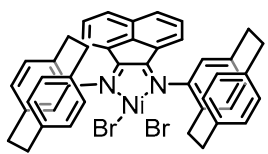

$\mathrm{NiBr}_{2}(\mathbf{L} \mathbf{1})$

$96 \%$

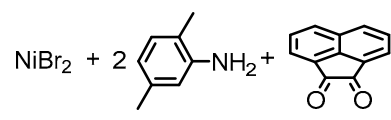

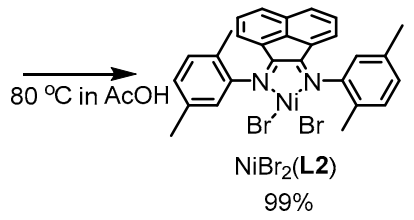

Figure 3 shows the molecular structure of $\mathrm{NiBr}_{2}(\mathbf{L} 1)$ determined by X-ray crystallography [61]. Two [2.2]paracyclophanyl substituents are orientated to the opposite side of the acenaphtene group. The Ni center has the distorted tetrahedral structure, suggesting paramagnetic high-spin complex of a $d^{8}$ metal center. The [2.2]paracyclophanyl substituents of the ligand are expected to influence stability of the intermediates with polymer and monomer ligands and selectivity of the reaction.

The crystal structure indicates that the ligand and $\mathrm{Ni}$ center forms a $C_{2}$ symmetrical space around the Ni center. Ni and Pd complexes $\mathbf{1 k}, \mathbf{1 1}, \mathbf{1 n}$ in Chart 1 also have coordination of the diimine ligand with $C_{2}$ symmetrical structures. Polymerization of olefins using these complexes as the catalyst was reported to occur stereoelectively. Investigation of a dinickel catalyst having a $C_{2}$ symmetrical space around the $\mathrm{Ni}(\mathrm{II})$ center revealed relevance of the detailed coordination structure of the complex to productivity and selectivity of the catalysis [62]. 

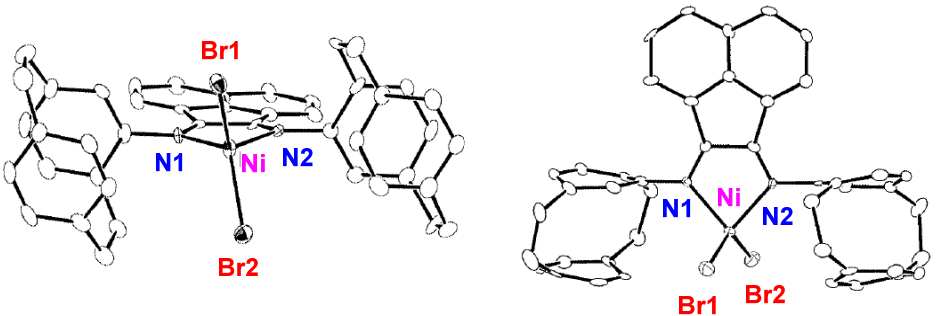

Figure 3. Crystallographic structure of $\mathrm{NiBr}_{2}(\mathbf{L 1}) \cdot\left(\mathrm{C}_{2} \mathrm{H}_{4} \mathrm{Cl}_{2}\right)$. Selected bond distances $(\AA)$ and angles ${ }^{\circ}{ }^{\circ}$ : Ni1-Br1 2.3375(15), Ni1-Br2 2.3392(16), Ni1-N1 2.028(5), Ni1-N2 2.035(5), Br1-Ni1-Br2 128.90(5), Br1-Ni1-N1 104.45(15), Br1-Ni1-N2 113.19(15), Br2-Ni1-N2 104.02(15), Br2-Ni1-N1 113.54(15), N1-Ni1-N2 83.7(2). The solvent molecule and hydrogen atoms are omitted for simplicity.

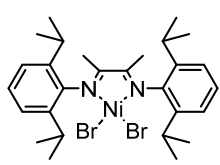

$1 \mathrm{a}$

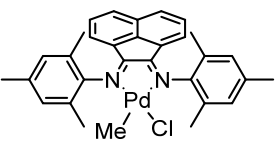

$1 \mathrm{e}$
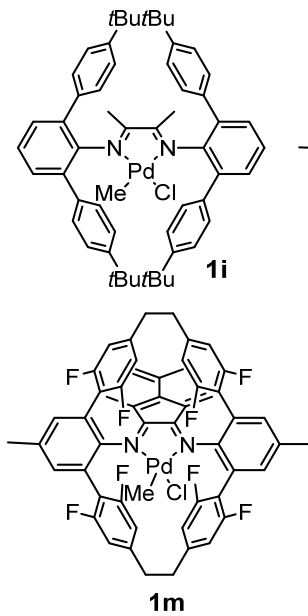

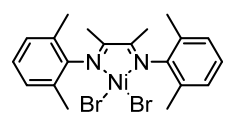

1c

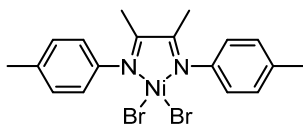

$1 \mathrm{~g}$
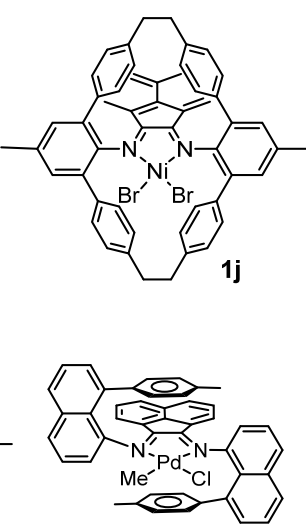

$1 \mathrm{n}$
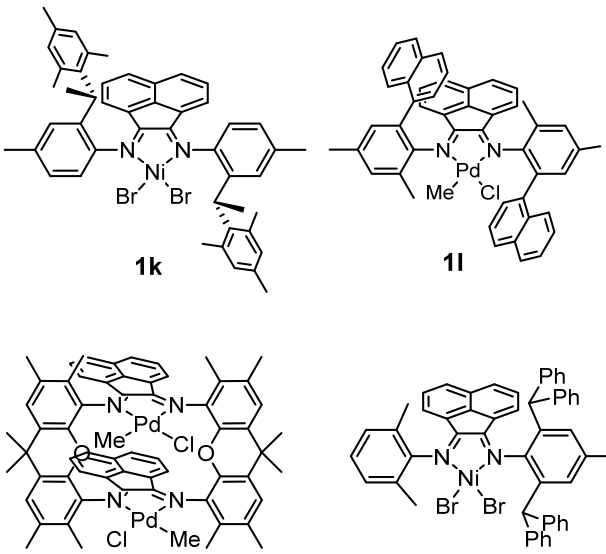

10

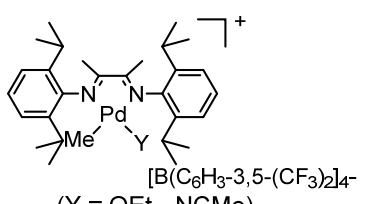

$\left(\mathrm{Y}=\mathrm{OEt}_{2}, \mathrm{NCMe}\right)$

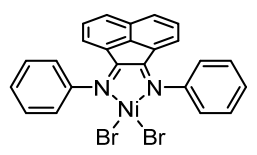

$1 \mathrm{~h}$

Chart 1. Ni and Pd diimine complexes for catalytic polymerization and oligomerization.

\subsection{Olefin Oligomerization Catalyzed by Ni Complexes}

Oligomerization of ethylene and 1-hexene was studied by using $\mathrm{NiBr}_{2}(\mathbf{L 1})$ as the catalyst and methylaluminoxane (MAO) as the co-catalyst. Table 1 summarizes results of ethylene oligomerization catalyzed by $\mathrm{NiBr}_{2}(\mathbf{L 1})$. The reactions at $10^{\circ} \mathrm{C}$ form mixtures of 1-butene and 2-butene (entries 1,2). The reactions at $25^{\circ} \mathrm{C}$ form the butenes in larger amounts and C6 hydrocarbon products, as confirmed by GPC analysis (entries 3-6). 
Table 1. Ethylene oligomerization catalyzed by $\mathrm{NiBr}_{2}(\mathbf{L 1})^{\text {a }}$

\begin{tabular}{|c|c|c|c|c|c|c|c|}
\hline \multirow{2}{*}{ Entry } & \multirow{2}{*}{ Catalyst } & \multicolumn{2}{|c|}{ Conditions } & \multicolumn{3}{|c|}{ Products/mmol } & \multirow{2}{*}{$\mathrm{C} 4 \mathrm{TOF} / \mathrm{h}^{-1 \mathrm{~b}}$} \\
\hline & & Temp $/{ }^{\circ} \mathrm{C}$ & Time/h & 1-Butene & 2-Butene & Hexenes & \\
\hline 1 & $\mathrm{NiBr}_{2}(\mathbf{L 1})$ & 10 & 3 & 0.32 & 0.11 & 0.00 & 29 \\
\hline 2 & $\mathrm{NiBr}_{2}(\mathbf{L 1})$ & 10 & 6 & 0.85 & 0.90 & 0.00 & 58 \\
\hline 3 & $\mathrm{NiBr}_{2}(\mathbf{L 1})$ & 25 & 1 & 0.15 & 0.05 & 0.01 & 40 \\
\hline 4 & $\mathrm{NiBr}_{2}(\mathbf{L 1})$ & 25 & 3 & 0.67 & 0.63 & 0.10 & 86 \\
\hline 5 & $\mathrm{NiBr}_{2}(\mathbf{L 1})$ & 25 & 6 & 0.98 & 2.78 & 0.75 & 126 \\
\hline 6 & $\mathrm{NiBr}_{2}(\mathbf{L 1})$ & 25 & 8 & 0.99 & 3.75 & 1.10 & 124 \\
\hline 7 & $\mathrm{NiBr}_{2}(\mathbf{L} 2)$ & 25 & 1 & $-{ }^{c}$ & $-{ }^{c}$ & $-{ }^{c}$ & $-{ }^{c}$ \\
\hline 8 & $\mathrm{NiBr}_{2}(\mathbf{L 1})$ & 50 & 3 & 0.12 & 0.18 & 0.00 & 20 \\
\hline 9 & $\mathrm{NiBr}_{2}(\mathbf{L 1})$ & 50 & 6 & 0.20 & 0.34 & 0.00 & 18 \\
\hline
\end{tabular}

a Conditions: [Ni] $0.010 \mathrm{mmol}, \mathrm{MAO}$ co-catalyst $([\mathrm{Al}] /[\mathrm{Ni}]=300)$, toluene $1 \mathrm{~mL}$, ethylene $1 \mathrm{~atm} .{ }^{\mathrm{b}} \mathrm{TOF}[\mathrm{mol}$ $(2 \times \mathrm{C} 4)][\text { mol cat. }]^{-1} \mathrm{~h}^{-1}$. ${ }^{\mathrm{c}}$ The product was polyethylene with $M_{\mathrm{n}}=1000$ (GPC).

The reaction yields 1- and 2-butenes in 3:1 molar ratio after $1 \mathrm{~h}$, while further reaction causes relative increase of 2-butene and formation of hexenes after $3 \mathrm{~h}$. Figure 4 plots time profile of the reaction, which suggests that initially formed 1-butene is isomerized into 2-butene during the reaction. Turn over frequency (TOF) for formation of the butenes increases for initial $6 \mathrm{~h}$, and becomes constant after $6 \mathrm{~h}$. It suggests that active species of the catalysis are increased slowly under the conditions.

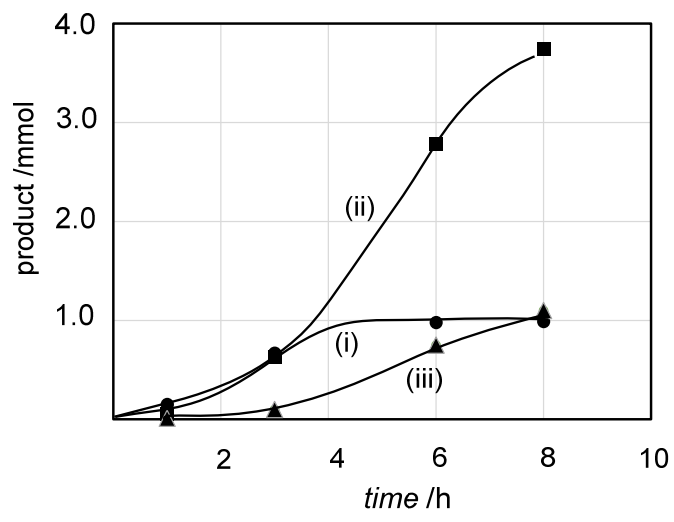

Figure 4. Reaction profile of ethylene oligomerization catalyzed by $\mathrm{NiBr}_{2}$ (L1)-MAO; (i) 1-butene, (ii) 2-butene, (iii) 1-hexene. Ethylene: $1 \mathrm{~atm}, \mathrm{Ni}: 0.010 \mathrm{~mol},[\mathrm{Al}] /[\mathrm{Ni}]=300$, toluene $10 \mathrm{~mL}, 25^{\circ} \mathrm{C}$. Product amounts are determined by GPC analysis.

Maximum TOF of the reaction is calculated from the total amount of 1- and 2-butenes to be $124-126\left(\mathrm{~h}^{-1}\right)$ under $1 \mathrm{~atm}$ ethylene at $25{ }^{\circ} \mathrm{C}$ (entries 5, 6). Ni-diimine complex with 4-methylphenyl substituents at the imine nitrogen, $\mathbf{1 g}$, was reported to catalyze ethylene oligomerization to $\alpha$-olefins up to $\mathrm{C} 20$ with TOF of $53,000-57,000\left(\mathrm{~h}^{-1}\right)$ at $35^{\circ} \mathrm{C}$ under $56 \mathrm{~atm}$ of ethylene [42]. TOF of the reaction catalyzed by $\mathrm{NiBr}_{2}(\mathbf{L 1})$ and averaged carbon number of the products are smaller than $1 \mathrm{~g}$, even when different temperature and ethylene pressure are considered. It is ascribed to severe steric hindrance of the Ni center of $\mathrm{NiBr}_{2}(\mathbf{L 1})$ bonded with the diimine ligand with [2.2]paracyclophane substituents. Reaction of ethylene catalyzed by $\mathrm{NiBr}_{2}(\mathbf{L} 2)$ under similar conditions did not form C4- nor C6oligomers, but produced a low molecular weight polyethylene as a wax solid $\left(M_{\mathrm{n}}=1000\right.$, $M_{\mathrm{w}} / M_{\mathrm{n}}=2.87$ based on GPC using polystyrene standards) (entry 7). The activity of the reaction by $\mathrm{NiBr}_{2}(\mathbf{L} \mathbf{1})$ catalyst at $50{ }^{\circ} \mathrm{C}$ is much lower than $25^{\circ} \mathrm{C}$ (entries 8,9).

The catalytic activity of $\mathrm{NiBr}_{2}(\mathbf{L} \mathbf{1})$ is compared with the Ni-diimine complexes reported so far. The Ni complex having 4-alkylphenyl groups at the imine nitrogen of the diamine ligand catalyzes ethylene oligomerization with high TOF because of frequent $\beta-$ hydrogen elimination of the oligomers caused by associative exchange of the coordinated 
oligomer molecule by a new ethylene monomer [42]. The complex with 2,5-disubstituted phenyl group, $\mathrm{NiBr}_{2}(\mathbf{L} 2)$, also produces the oligomer with $M_{n}=1000$, as shown above. The complexes having bulky 2,6-disubstituted or 2,4,6-trisubstituted aryl groups at the diimine nitrogen catalyze high mass polymerization of ethylene because the associative chain transfer of the polymer molecule is inhibited strictly by the bulky aryl groups at the imine nitrogen [41]. $\mathrm{NiBr}_{2}(\mathbf{L 1})$ of this study has a more bulky ligand than the ligands of the above studies, and catalyzes dimerization and trimerization of ethylene.

Reaction of 1-hexene catalyzed by $\mathrm{NiBr}_{2}(\mathbf{L 1})-\mathrm{MAO}([\mathrm{Al}] /[\mathrm{Ni}]=300)$ causes isomerization of the substrate to 2-hexene and dimerization and trimerization of 1-hexene to form $\mathrm{C} 12$ and $\mathrm{C} 18$ products. The isomerization occurs more readily than the oligomerization under the examined conditions. Results of the reactions under different conditions are summarized in Table 2 . The reactions at $10{ }^{\circ} \mathrm{C}$ with $\mathrm{MAO}([\mathrm{Al}] /[\mathrm{Ni}]=300)$ and at $25^{\circ} \mathrm{C}$ with a smaller amount of $\mathrm{MAO}([\mathrm{Al}] /[\mathrm{Ni}]=50)($ entries $1-3)$ show lower catalytic activity than those at $25^{\circ} \mathrm{C}$ and $[\mathrm{Al}] /[\mathrm{Ni}]=300$ (entry 4, 5). At $35{ }^{\circ} \mathrm{C}$ and $50{ }^{\circ} \mathrm{C}$, TOF for the oligomerization is high for the initial $0.5 \mathrm{~h}\left(28\right.$ and $61 / \mathrm{h}^{-1}$, respectively) and become much lower after $6 \mathrm{~h}$. It indicates that the catalytic activity decreases rapidly for several hours. The addition of MAO in a larger amount $([\mathrm{Al}] /[\mathrm{Ni}]=1000)$ does not increase the oligomer yields. The product ratios after the reaction for $24 \mathrm{~h}$ vary depending on the temperature (entries 2, 5, 9, 12), which is shown in Figure 5. The reaction for $24 \mathrm{~h}$ at $50{ }^{\circ} \mathrm{C}$ forms the trimer as the main product (entry 12). Use of modified methylaluminoxane (MMAO) as the co-catalyst decreases the oligomer yields (entry 13). The reactions using $\mathrm{AlMe}_{3}$ and $\mathrm{Et}_{2} \mathrm{AlCl}$ co-catalysts yield 2-hexene exclusively (entries 14,15).

Table 2. Oligomerization of 1-hexene catalyzed by $\mathrm{NiBr}_{2}(\mathbf{L 1})^{\text {a }}$.

\begin{tabular}{cccccccc}
\hline \multirow{2}{*}{ Entry } & Co-Catalyst & \multicolumn{2}{c}{ Conditions } & \multicolumn{3}{c}{ Products (\%) } & \multirow{2}{*}{$\begin{array}{c}\text { C12,C18 } \\
\text { TOF/h }\end{array}$} \\
\cline { 3 - 6 } & & Temp/ ${ }^{\circ} \mathbf{C}$ & Time/h & 2-Hexene & C12 & C18 & \\
\hline 1 & MAO (300) & 10 & 6 & 34 & 2.9 & 6.6 & 4.8 \\
2 & MAO (300) & 10 & 24 & 79 & 9.5 & 8.6 & 2.3 \\
3 & MAO (50) & 25 & 24 & 66 & 2.6 & 17 & 2.5 \\
4 & MAO (300) & 25 & 6 & 56 & 7.3 & 13 & 10.2 \\
5 & MAO (300) & 25 & 24 & 62 & 11 & 18 & 3.6 \\
6 & MAO (1000) & 25 & 24 & 21 & 2.1 & 18 & 2.5 \\
7 & MAO (300) & 35 & 0.5 & 33 & 4.6 & 0.0 & 28 \\
8 & MAO (300) & 35 & 6 & 54 & 16 & 5.6 & 11 \\
9 & MAO (300) & 35 & 24 & 45 & 22 & 28 & 6.3 \\
10 & MAO (300) & 50 & 0.5 & 49 & 7.2 & 3.0 & 61 \\
11 & MAO (300) & 50 & 6 & 40 & 11 & 34 & 23 \\
12 & MAO (300) & 50 & 24 & 23 & 12 & 57 & 8.6 \\
13 & MMAO (300) & 25 & 6 & 37 & 6.8 & 18 & 12 \\
14 & AlMe (300) & 50 & 1 & 98 & 0.0 & 0.0 & 0.0 \\
15 & Et $_{2}$ AlCl (300) & 50 & 1 & 95 & 0.0 & 0.0 & 0.0 \\
\hline
\end{tabular}

a Conditions: catalyst $\mathrm{NiBr}_{2}(\mathrm{L1})$, [Ni] $0.010 \mathrm{mmol}$, [1-hexene]/[Ni] = 300, solvent toluene $(1.5 \mathrm{~mL}) .{ }^{\mathrm{b}}$ [Al] / [Ni] is shown in parenthesis.

Figure 6 shows time-conversion (a) and first-order plots (b) of the total reaction at $10^{\circ} \mathrm{C}, 25^{\circ} \mathrm{C}, 35^{\circ} \mathrm{C}$, and $50^{\circ} \mathrm{C}$. The reaction obeys first-order kinetics to the concentration of 1-hexene. The kinetic parameters of the reaction were determined from Eyring plots to be $\Delta G^{\ddagger}=93.6 \mathrm{~kJ} \mathrm{~mol}^{-1}, \Delta H^{\ddagger}=63.0 \mathrm{~kJ} \mathrm{~mol}^{-1}, \Delta S^{\ddagger}=-112 \mathrm{~J} \mathrm{~mol}^{-1} \mathrm{deg}^{-1}$. Isomerization of 1hexene into 2-hexene proceeds via insertion of the olefin into a $\mathrm{Ni}-\mathrm{H}$ bond and subsequent $\beta$-hydrogen elimination of the internal olefin. Formation of C12 and C18 products is induced by insertion of 1-hexene into the $\mathrm{Ni}-\mathrm{C}$ bond followed by $\beta$-hydrogen elimination of the products. The above kinetics for the reaction suggests that insertion of 1-hexene into the $\mathrm{Ni}-\mathrm{H}$ and $\mathrm{Ni}-\mathrm{C}$ bonds is the rate-determining step of the reaction. 


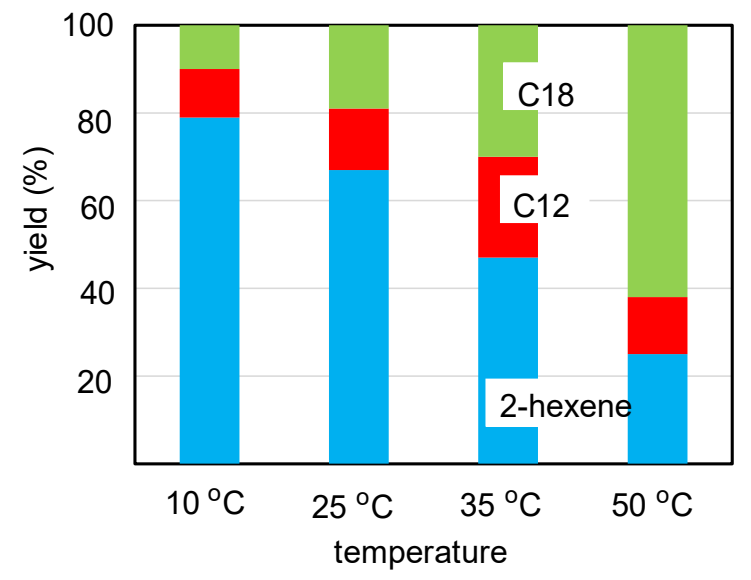

Figure 5. Temperature effect of oligomerization of 1-hexene. 1-Hexene: $3.0 \mathrm{mmol}, \mathrm{Ni}: 0.010 \mathrm{~mol}$, $[\mathrm{Al}] /[\mathrm{Ni}]=300$, toluene $10 \mathrm{~mL}, 24 \mathrm{~h}$. Conversion of 1 -hexene is $83-95 \%$ for the reactions.

(a)

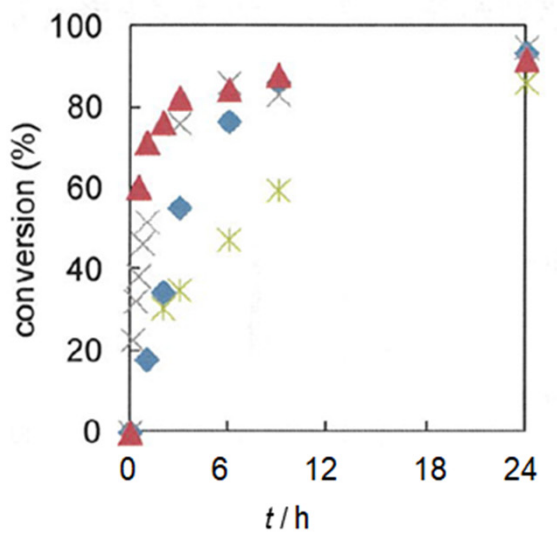

(b)

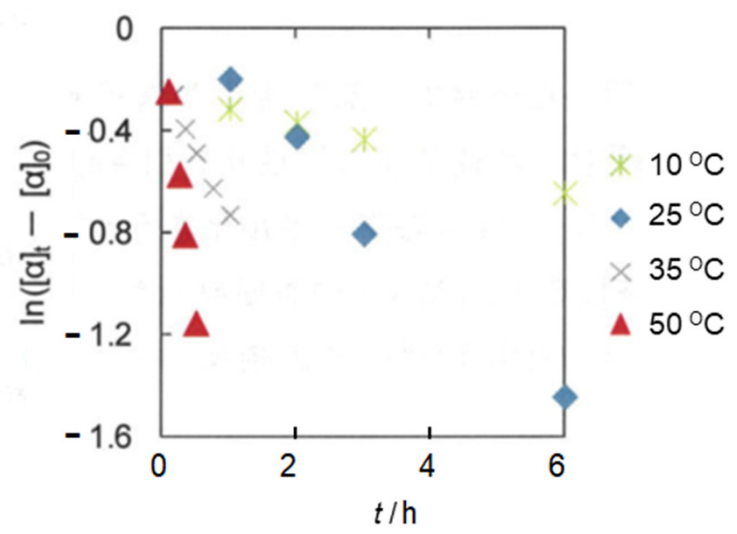

Figure 6. Oligomerization of 1-hexene catalyzed by $\mathrm{NiBr}_{2}(\mathbf{L 1})-\mathrm{MAO}$. (a) Time conversion of 1-hexene at $25^{\circ} \mathrm{C}$. (b) First-order plots of the total reaction.

Reaction of a mixture of ethylene and 1-hexene catalyzed byNiBr $2(\mathbf{L 1})-\mathrm{MMAO}$ formed $\mathrm{C} 8$ products in a higher amount than $\mathrm{C} 10-\mathrm{C} 16$ products. Figure 7 compares results of GLC measurement of the reaction mixture with that of ethylene oligomerization under similar conditions. The products of the reaction of 1-hexene under ethylene atmosphere contain C8 (0.92 mmol), C10 (0.24 mmol), and C12 (0.095 mmol), as shown in Figure 7a. Figure $7 \mathrm{~b}$ shows the results of the reaction of ethylene, producing $\mathrm{C} 4$ and $\mathrm{C} 6$ hydrocarbons in main. The amounts of higher hydrocarbon products, C8 (0.076 mol), C10 $(0.046 \mathrm{mmol})$, and $\mathrm{C} 12(0.017 \mathrm{mmol})$, are smaller than the reaction of ethylene and 1-hexene, as shown in Figure $7 \mathrm{~b}$. Thus, the reaction of ethylene and 1-hexene forms the hydrocarbon via crossdimerization much more rapidly than tetramerization of ethylene and cross-trimerization (C10 hydrocarbons), and cross-tetramerization (C12 hydrocarbons). The experimental results at present, however, are not sufficient to discuss detailed reaction pathways for the selective cross-dimerization. 


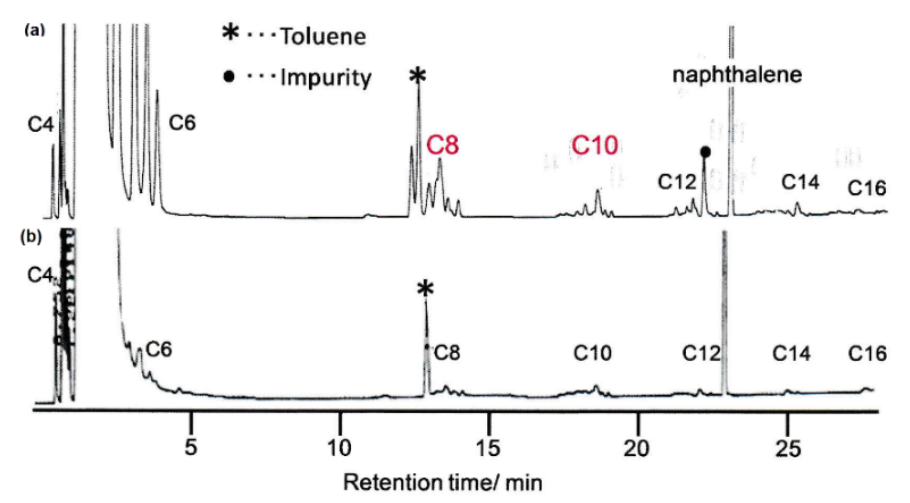

Figure 7. GC elution of the product. (a) Reaction of ethylene and 1-hexene catalyzed by $\mathrm{NiBr}_{2}(\mathbf{L 1})$ -MMAO. (b) Reaction of ethylene catalyzed by $\mathrm{NiBr}_{2}(\mathbf{L 1})$-MMAO. Ni complex 0.010 mmol, $[\mathrm{Al}] /[\mathrm{Ni}]=300$. Pentane $8 \mathrm{~mL}, 25^{\circ} \mathrm{C}, 24 \mathrm{~h}$.

\section{Conclusions}

This paper presents diastereoselective preparation of dimine ligand L1 with two [2.2]paracyclophanyl groups, via condensation of acenaphtenequinone with two equivalents of amino[2.2]paracyclopheylene, and its complexation with $\mathrm{Ni}(\mathrm{II})$ center to form $\mathrm{NiBr}_{2}(\mathbf{L 1})$. X-ray crystallographic results of $\mathrm{NiBr}_{2}(\mathbf{L 1})$ showed the molecular structure whose paracyclophanyl groups are at the positions close to the Ni center. The complex, in the presence of MAO co-catalyst, catalyzes oligomerization of ethylene to form mixtures of 1- and 2-butenes at $10-50{ }^{\circ} \mathrm{C}$ with the highest TOF for butene formation $\left(126 \mathrm{~h}^{-1}\right)$. The reaction of 1-hexene using the same catalyst causes isomerization into 2-hexene and oligomerization to $\mathrm{C} 12$ and $\mathrm{C} 18$ products. The total reaction obeys first-order kinetics to the amount of 1-hexene, suggesting the rate-determining step at the insertion of 1-hexene into $\mathrm{Ni}-\mathrm{H}$ and $\mathrm{Ni}-\mathrm{C}$ bonds. $\mathrm{NiBr}_{2}(\mathbf{L} \mathbf{1})$ catalyzes cross-dimerization of ethylene with 1-hexene to form $\mathrm{C} 8$ products in the presence of MMAO, which occurs more readily than tetramerization of ethylene and than the cross-oligomerization of the two olefins, giving C10 and C12 products, under the same conditions. Thus, $\mathrm{NiBr}_{2}(\mathbf{L 1})$ with an extremely bulky diimine ligand catalyze dimerization and trimerization of ethylene rather than formation of higher oligomers or high mass polymers. The unique properties of the catalysis is a selective formation of the cross-dimer of ethylene and 1-hexene. The elucidation of the mechanism for the selective co-dimerization reaction is a problem left for future research.

\section{Experimental Section}

\subsection{General}

All the chemicals were commercially available. MAO and MMAO were purchased from Tosoh Co. Ltd. (Tokyo, Japan) as toluene solutions. ${ }^{1} \mathrm{H}$ and ${ }^{13} \mathrm{C}\left\{{ }^{1} \mathrm{H}\right\}$ NMR spectra were acquired on a Bruker AV-400M. The chemical shifts were referenced with respect to $\mathrm{CHCl}_{3}(\delta 7.26), \mathrm{HDO}(\delta 4.79)$ for ${ }^{1} \mathrm{H}$, and $\mathrm{CDCl}_{3}(\delta$ 77.0), DSS (sodium 3-(trimethylsilyl)-1propanesulfonate) $(\delta 0.0)$ for ${ }^{13} \mathrm{C}$ as internal standards.

\subsection{Preparation of Racemic Ligand $\mathbf{L} \mathbf{1}$}

(rac)-Amino[2.2]paracylophane was prepared by the reported method [63], and modification of the final step, Curtius rearrangement, results in the product in overall $61 \%$ yield. A mixture of rac-amino[2.2]paracyclophane $(0.40 \mathrm{~g}, 1.8 \mathrm{mmol})$, acenaphtenequinone $(0.15 \mathrm{~g}$, $0.81 \mathrm{mmol})$, and a small amount of acetic acid in $\mathrm{EtOH}(35 \mathrm{~mL})$ was heated for $35 \mathrm{~h}$ under reflux. After removal of the solvent, purification by silica gel column (hexane $/ \mathrm{CH}_{2} \mathrm{Cl}_{2}, 2: 1$; $\left.R_{\mathrm{f}}=0.3\right)$ yielded ligand $\mathbf{L} 1$ as an orange solid $(0.26 \mathrm{~g}, 0.43 \mathrm{mmol}, 53 \%)$. The ${ }^{1} \mathrm{H}$ and ${ }^{13} \mathrm{C}\left\{{ }^{1} \mathrm{H}\right\}$ NMR spectra indicated the presence of conformation isomer whose structural details were not clarified. The obtained ligand was used for preparation of the complex directly. Anal. Calcd for $\mathrm{C}_{44} \mathrm{H}_{36} \mathrm{~N}_{2}$ : C 89.15; H 6.12; N 4.73. Found C 89.28; H 6.12, N 4.60. 


\subsection{Preparation of Optically Active Ligand $\mathbf{L} \mathbf{1}$}

A mixture of (R)-(-)-amino[2.2]paracyclophane (50 mg, $0.22 \mathrm{mmol}$ ) [64-68] and acetonaphtequinone $(19 \mathrm{mg}, 0.10 \mathrm{mmol})$ and a small amount of acetic acid in $\mathrm{EtOH}$ was heated for $24 \mathrm{~h}$ under reflux. Purification by alumina column (hexane $/ \mathrm{CH}_{2} \mathrm{Cl}_{2}, 2: 1 ; \mathrm{R}_{\mathrm{f}}=0.3$ ) yielded ligand $\mathbf{L 1}$ as an orange solid (34 mg, $0.56 \mathrm{mmol}, 50 \%$ ). The ${ }^{1} \mathrm{H}$ and ${ }^{13} \mathrm{C}\left\{{ }^{1} \mathrm{H}\right\}$ NMR spectra are identical with the compound formed from racemic starting materials. Anal. Calcd for $\mathrm{C}_{44} \mathrm{H}_{36} \mathrm{~N}_{2} .0 .3 \mathrm{H}_{2} \mathrm{O}$ : C 88.35; H 6.17; N 4.68. Found C 88.25; H 5.98, N 4.65.

\subsection{Preparation of $\mathrm{NiBr}_{2}(\mathbf{L 1})$}

A mixture of $\mathrm{NiBr}_{2}$ (dme) (dme: 1,2-dimethoxyethane) $(120 \mathrm{mg}, 0.39 \mathrm{mmol})$ and (rac)L1 $(240 \mathrm{mg}, 0.41 \mathrm{mmol})$ in $\mathrm{Et}_{2} \mathrm{O}$ was stirred for $24 \mathrm{~h}$ at room temperature. The resulted solid was obtained by filtration, washed with $\mathrm{Et}_{2} \mathrm{O}$ to yield $\mathrm{NiBr}_{2}(\mathbf{L 1})$ as an dark brown solid ( $280 \mathrm{mg}, 0.34 \mathrm{mmol}, 96 \%$ ). Anal. Calcd for $\mathrm{C}_{44} \mathrm{H}_{36} \mathrm{~N}_{2} \mathrm{Br}_{2} \mathrm{Ni}$ : C 65.14; $\mathrm{H}$ 4.47; N 3.45 . Found C 65.39; H 4.50, N 3.29. The reaction of $(R, R)-\mathbf{L 1}$ with $\mathrm{NiBr}_{2}(\mathrm{dme})$ was carried out analogously.

\subsection{X-ray Crystallography of $\mathrm{NiBr}_{2}(\mathbf{L 1})$}

Single crystals of $\mathrm{NiBr}_{2}(\mathbf{L 1}) \cdot\left(\mathrm{C}_{2} \mathrm{H}_{4} \mathrm{Cl}_{2}\right)$ suited to X-ray diffraction study were obtained by recrystallization from 1,2-dichloroethane- $\mathrm{Et}_{2} \mathrm{O}$, and mounted on MicroMounts (MiTeGen). The crystallographic data were collected on a Bruker SMART APEXII ULTRA/CCD diffractometer equipped with monochromated Mo K $\alpha$ radiation $(\lambda=0.71073 \AA)$. Calculations were carried out using the program package Olex2 [69]. Crystallographic data have been deposited with the Cambridge Crystallographic Data Centre: deposition number CCDC-2076633, which can be obtained free of charge via http://www.ccdc.cam.ac.uk/ conts/retrieving.html.

\subsection{Preparation of $\mathrm{NiBr}_{2}(\mathbf{L} 2)$}

A mixture of $\mathrm{NiBr}_{2}(200 \mathrm{mg}, 0.90 \mathrm{mmol}), 2,5$-dimethylaniline $(0.26 \mathrm{~mL}, 2.2 \mathrm{mmol})$, and acetonaphthenequinone $(180 \mathrm{mg}, 1.00 \mathrm{mmol})$ was dissolved in acetic acid $(5 \mathrm{~mL})$ at $80^{\circ} \mathrm{C}$. After heating for $1 \mathrm{~h}$ at the temperature, the resulted solid was collected by filtration, washed with acetic acid and then $\mathrm{Et}_{2} \mathrm{O}$, and dried in vacuo to give $\mathrm{NiBr}_{2}(\mathbf{L} 2)$ as a yellow brown solid (540 mg, $0.89 \mathrm{mmol}, 99 \%$ ). Anal. Calcd for $\mathrm{C}_{28} \mathrm{H}_{24} \mathrm{~N}_{2} \mathrm{Br}_{2} \mathrm{Ni} \cdot 0.5 \mathrm{H}_{2} \mathrm{O}$ : C 54.59; H 4.09; N 4.55. Found C 54.47; H 4.25, N 4.38.

\subsection{Oligomerization}

\subsubsection{Oligomerization of Ethylene}

To a $25 \mathrm{~mL}$ Schlenk flask containing $\mathrm{NiBr}_{2}(\mathbf{L 1})(0.10 \mathrm{mmol})$ under nitrogen atmosphere was added dried toluene $(10 \mathrm{~mL})$ and naphthalene $(64 \mathrm{mg}$, internal standard). The system was degassed by two freeze-thaw cycles. The flask was connected to a balloon filled with ethylene $(1 \mathrm{~atm})$, and MAO solution $([\mathrm{Al}] /[\mathrm{Ni}]=300)$ was added to the mixture through septum. The reaction was conducted in a thermostated bath. A part of the product was extracted from the system by a syringe and analyzed by ${ }^{1} \mathrm{H}$ NMR and GLC.

\subsubsection{Oligomerization of 1-Hexene}

To a $25 \mathrm{~mL}$ Schlenk flask containing $\mathrm{NiBr}_{2}(\mathbf{L} 1)(0.10 \mathrm{mmol})$ under nitrogen atmosphere was added dried toluene $(1.5 \mathrm{~mL}$ ) and a hexane solution of naphthalene (internal standard). The system was degassed by two freeze-thaw cycles, and the flask was filled with nitrogen. A hexane solution of $\mathrm{MAO}([\mathrm{Al}] /[\mathrm{Ni}]=300)$ was added through septum, and the reaction was carried out in a thermostated bath. A part of the product was extracted from the mixture, and analyzed by ${ }^{1} \mathrm{H}$ NMR and GLC.

\subsubsection{Co-Dimerization of Ethylene and 1-Hexene}

A toluene solution of MMAO was evacuated to remove the solvent, and the remaininig MMAO was dissolved in pentane. To a $25 \mathrm{~mL}$ Schlenk flask containing $\mathrm{NiBr}_{2}(\mathbf{L 1})$ 
$(0.10 \mathrm{mmol})$ under nitrogen atmosphere was added a pentane $(5 \mathrm{~mL})$ solution of 1-hexene and naphthalene (internal standard). The flask was connected to a balloon filled with ethylene (1 atm). The pentane solution of MMAO was added to the system via a syringe through septum. The reaction was carried out in a thermostatted bath, and a part of the product was extracted from the solution via a syringe.

Author Contributions: Conceptualization, D.T.; methodology, D.T.; investigation, D.T. and Y.-a.T.; writing—original draft preparation, K.O.; writing—review and editing, K.O.; supervision, K.O.; funding acquisition, D.T. All authors have read and agreed to the published version of the manuscript.

Funding: This research was funded by Research Grant from JSPS, grant number 22685012 and 23655098.

Institutional Review Board Statement: Not Applicable.

Informed Consent Statement: Not Applicable.

Data Availability Statement: Data is contained within this article.

Acknowledgments: The authors are grateful to 'Dynamic Alliance for Open Innovation Bridging' from the Ministry of Education, Culture, Sports, Science and Technology of Japan (MEXT) for their support. We thank our colleagues in Center for Advanced Materials Analysis of our institute, Tokyo Institute of Technology for NMR (Yoshihisa Sei), elemental analysis (Chieko Hara), X-ray crystallography (Yoshihisa Sei, Center for Advanced Materials Analysis).

Conflicts of Interest: The authors declare no conflict of interest.

\section{References}

1. Skupinska, J. Oligomerization of $\alpha$-Olefins to Higher Oligomers. Chem. Rev. 1991, 91, 613-648. [CrossRef]

2. Dixon, J.T.; Green, M.J.; Hess, F.M.; Morgan, D.H. Advances in Selective Ethylene Trimerisation-A Critical Overview. J. Organomet. Chem. 2004, 689, 3641-3668. [CrossRef]

3. Speiser, F.; Braustein, P.; Saussine, L. Catalytic Ethylene Dimerization and Oligomerization: Recent Developments with Nickel Complexes Containing P, N-Chelating Ligands. Acc. Chem. Res. 2005, 38, 784-793. [CrossRef] [PubMed]

4. Bianchini, C.; Giambastiani, G.; Rios, I.G.; Mantovani, G.; Meli, A.; Segarra, A.M. Ethylene Oligomerization, Homopolymerization and Copolymerization by Iron and Cobalt Catalysts with 2,6-(Bis-organylimino)pyridyl Ligands. Coord. Chem. Rev. 2006, 250, 1391-1418. [CrossRef]

5. Kuhn, P.; Sémeril, D.; Matt, D.; Chetcuti, M.J.; Lutz, P. Structure-Reactivity Relationships in SHOP-Type Complexes: Tunable Catalysts for the Oligomerisation and Polymerisation of Ethylene. Dalton Trans. 2007, 515-528. [CrossRef]

6. Wass, D.F. Chromium-Catalysed Ethylene Trimerization and Tetramerisation-Breaking the Rules in Olefin Oligomerisation. Dalton Trans. 2007, 816-819. [CrossRef] [PubMed]

7. Belov, G.P. Selective Dimerization, Oligomerization, Homopolymerization and Copolymerization of Olefins, with Complex Organometallic Catalysts. Russ. J. Appl. Chem. 2008, 81, 1655-1666. [CrossRef]

8. McGuinness, D. Alkene Oligomerisation and Polymerisation with Metal-NHC Based Catalysts. Dalton Trans. 2009, 6915-6923. [CrossRef]

9. Takeuchi, D.; Osakada, K. Oligomerization of Olefins. In Organometallic Reactions and Polymerization; Springer: Berlin/Heidelberg, Germany, 2010; pp. 169-215.

10. Fujita, T.; Kawai, K. FI Catalysts for Olefin Oligomerization and Polymerization: Production of Useful Olefin-Based Materials by Unique Catalysis. Top. Catal. 2014, 57, 852-877. [CrossRef]

11. Bianchini, C.; Giambastiani, G.; Luconi, L.; Meli, A. Olefin Oligomerization, Homopolymerization and Copolymerization by Late Transition Metals Supported by (Imino)pyridine Ligands. Coord. Chem. Rev. 2010, 254, 431-455. [CrossRef]

12. Agapie, T. Selective Ethylene Oligomerization: Recent Advances in Chromium Catalysis and Mechanistic Investigations. Coord. Chem. Rev. 2011, 255, 861-880. [CrossRef]

13. van Leeuwen, P.W.N.M.; Clément, N.D.; Tschan, M.J.-L. New Processes for the Selective Production of 1-Octene. Coord. Chem. Rev. 2011, 255, 1499-1517. [CrossRef]

14. Zhang, W.; Sun, W.-H.; Redshaw, C. Tailoring Iron Complexes for Ethylene Oligomerization and/or Polymerization. Dalton Trans. 2013, 42, 8988-8997. [CrossRef] [PubMed]

15. Olivier-Bourbigou, H.; Breuil, P.A.R.; Magna, L.; Michel, T.; Pastor, M.F.E.; Delcroix, D. Nickel Catalyzed Olefin Oligomerization and Dimerization. Chem. Rev. 2020, 120, 7919-7983. [CrossRef]

16. Ishii, S.; Nakano, T.; Kawamura, K.; Kinoshita, S.; Ichikawa, S.; Fujita, T. Development of New Selective Ethylene Trimerization Catalysts Based on Highly Active Ethylene Polymerization Catalysts. Catal. Today 2018, 303, 263-270. [CrossRef]

17. Parfenova, L.V.; Kovyazin, P.V.; Bikmeeva, A.K. Bimetallic Zr, Zr-Hydride Complexes in Zirconocene Catalyzed Alkene Dimerization. Molecules 2020, 25, 2216. [CrossRef] 
18. Guo, J.; Chen, Q.; Zhang, W.; Liang, T.; Sun, W.-H. The Benzhydryl-modified 2-Imino-1,10-Phenanthryliron Precatalyst in Ethylene Oligomerization. J. Organomet. Chem. 2021, 936, 121713. [CrossRef]

19. Goetjen, T.A.; Zhang, X.; Liu, J.; Hupp, J.T.; Farha, O.K. Metal-Organic Framework Supported Single Site Chromium(III) Catalyst for Ethylene Oligomerization at Low Pressure and Temperature. ACS Sustainable Chem. Eng 2019, 7, 2553-2557. [CrossRef]

20. Katayama, H.; Yari, H.; Tanaka, M.; Ozawa, F. (Z)-Selective Cross-Dimerization of Arylacetylenes with Silylacetylenes Catalyzed by Vinylidenruthenium Complexes. Chem. Commun. 2005, 4336-4338. [CrossRef]

21. Xu, H.-D.; Zhang, R.-W.; Li, X.; Huang, S.; Tang, W.; Hu, W.-H. Rhodium-Catalyzed Chemo- and Regioselective CrossDimerization of Two Terminal Alkynes. Org. Lett. 2013, 15, 840-843. [CrossRef] [PubMed]

22. Hirano, M.; Komiya, S. Oxidative Coupling Reactions at Rutheium(0) and Their Applications to Catalytic Homo- and CrossDimerizations. Coord. Chem. Rev. 2016, 314, 182-200. [CrossRef]

23. Kiyota, S.; In, S.; Komine, N.; Hirano, M. Regioselectivity Control by Added MeCN in Ru(0)-catalyzed Cross-dimerization of Internal Alkynes with Methyl Methacrylate. Chem. Lett. 2017, 46, 1040-1043. [CrossRef]

24. Ueda, Y.; Tsurugi, H.; Mashima, K. Cobalt-Catalyzed E-Selective Cross-Dimerization of Terminal Alkynes: A Mechanism Involving Cobalt (0/II) Redox Cycles. Angew. Chem. Int. Ed. 2020, 59, 1552-1556. [CrossRef] [PubMed]

25. Brookhart, M.S.; Hauptman, E.M. Cross-Dimerization of Olefins. U.S. Patent US5892101A, 6 April 1999.

26. Nomura, N.; Jin, J.; Park, H.; RajanBabu, T.V. The Hydrovinylation Reaction: A New Highly Selective Protocol Amenable to Asymmetric Catalysis. J. Am. Chem. Soc. 1998, 120, 459-460. [CrossRef]

27. RajanBabu, T.V.; Nomura, N.; Jin, J.; Nandi, M.; Park, H.; Sun, X. Heterodimerization of Olefins. 1. Hydrovinylation Reactions of Olefins That Are Amenable to Asymmetric Catalysis. J. Org. Chem. 2003, 68, 8431-8446. [CrossRef]

28. RajanBabu, T.V. Asymmetric Hydrovinylation Reaction. Chem. Rev. 2003, 103, 2845-2860. [CrossRef]

29. Saha, B.; RajanBabu, T.V. Syntheses and Applications of 2-Phosphino-2'-alkoxy-1,1'-binaphthyl Ligands. Development of a Working Model for Asymmetric Induction in Hydrovinylation Reactions. J. Org. Chem. 2007, 72, 2357-2363. [CrossRef]

30. Fassina, V.; Ramminger, C.; Seferin, M.; Monteiro, A.L. Nickel Catalyzed Hydrovinylation of Arylethylenes: General Method of Synthesis of $\alpha$-Arylpropionic Acids Intermediates. Tetrahedron 2000, 56, 7403-7409. [CrossRef]

31. Yi, C.S.; He, Z.; Lee, D.W. Hydrovinylation of Alkenes Catalyzed by the Ruthenium-Hydride Complex Formed in Situ from $\left(\mathrm{PCy}_{3}\right)_{2}(\mathrm{CO}) \mathrm{RuHCl}$ and $\mathrm{HBF}_{4} \cdot \mathrm{OEt}_{2}$. Organometallics 2001, 20, 802-804. [CrossRef]

32. Sanchez, R.P., Jr.; Connell, B.T. A Ruthenium-Based Catalyst System for Hydrovinylation at Room Temperature. Organometallics 2008, 27, 2902-2904. [CrossRef]

33. Kondo, T.; Takagi, D.; Tsujita, H.; Ura, Y.; Wada, K.; Mitsudo, T. Highly Selective Dimerization of Styrenes and Linear Codimerization of Styrenes with Ethylene Catalyzed by a Ruthenium Complex. Angew. Chem. Int. Ed. 2007, 46, 5958-5961. [CrossRef]

34. Gooßen, L.J.; Rodríguez, N. Heterodimerization of Olefins: A Highly Promising Strategy for the Selective Synthesis of Functionalized Alkenes. Angew. Chem. Int. Ed. 2007, 46, 7544-7546. [CrossRef] [PubMed]

35. Takeuchi, D.; Takada, H.; Yamazaki, K.; Osakada, K. Hydrovinylation of Olefins Catalyzed by $\mathrm{RuCl}_{2}(\mathrm{MeCN})_{2}(\mathrm{cod}) / \mathrm{Organoalum}-$ inum System. Trans. Mat. Res. Soc. Jpn. 2019, 44, 137-141. [CrossRef]

36. Yamamoto, Y.; Ohkoshi, N.; Kameda, M.; Itoh, K. Ruthenium-Catalyzed Highly Efficient Intramolecular Olefin Coupling of $\alpha, \omega$-Dienes. Facile and Regioselective Synthesis of exo-Methylenecyclopentanes. J. Org. Chem. 1999, 64, 2178-2179. [CrossRef]

37. Yamamoto, Y.; Nakag, Y.; Ohkoshi, N.; Itoh, K. Ruthenium(II)-Catalyzed Isomer-Selective Cyclization of 1,6-Dienes Leading to exoMethylenecyclopentanes: Unprecedented Cycloisomerization Mechanism Involving Ruthenacyclopentane(hydrido) Intermediate. J. Am. Chem. Soc. 2001, 123, 6372-6380. [CrossRef] [PubMed]

38. Widenhoefer, R.A.; Perch, N.S. Silane-Promoted Cycloisomerization of Functionalized 1,6-Dienes Catalyzed by a Cationic ( $\pi$-Allyl)palladium Complex. Org. Lett. 1999, 1, 1103-1105. [CrossRef]

39. Kisanga, P.; Goj, L.A.; Widenhoefer, R.A. Cycloisomerization of Functionalized 1,5- and 1,6-Dienes Catalyzed by Cationic Palladium Phenanthroline Complexes. J. Org. Chem. 2001, 66, 635-637. [CrossRef] [PubMed]

40. Deckers, P.J.W.; Hessen, B.; Teuben, J.H. Catalytic Trimerization of Ethene with Highly Active Cyclopentadienyl-Arene Titanium Catalysts. Organometallics 2002, 21, 5122-5135. [CrossRef]

41. Johnson, L.K.; Killian, C.M.; Brookhart, M. New Pd(II)- and Ni(II)-Based Catalyst for Polymerization of Ethylene and $\alpha$-Olefins. J. Am. Chem. Soc. 1995, 117, 6414-6415. [CrossRef]

42. Killian, C.M.; Johnson, L.K.; Brookhart, M. Preparation of Linear $\alpha$-Olefins Using Cationic Nickel(II) $\alpha$-Diimine Catalysts. Organometallics 1997, 16, 2005-2007. [CrossRef]

43. Svejda, S.A.; Brookhart, M. Ethylene Oligomerization and Propylene Dimerization Using Cationic ( $\alpha$-Diimine)nickel(II) Catalysts. Organometallics 1999, 18, 65-74. [CrossRef]

44. Schmid, M.; Eberhardt, R.; Klinga, M.; Leskelä, M.; Rieger, B. New $C_{2 v}-$ and Chiral $C_{2}-$ Symmetric Olefin Polymerization Catalysts Based on Nickel(II) and Pallaium(II) Diimine Complexes Bearing 2,6-Diphenyl Aniline Moieties: Synthesis, Structural Characterization, and First Insight into Polymerization Properties. Organometallics 2001, 20, 2321-2330. [CrossRef]

45. Camacho, D.H.; Guan, Z. Living Polymerization of $\alpha$-Olefins at Elevated Temperatures Catalyzed by a Highly Active and Robust Cyclophane-Based Nickel Catalyst. Macromolecules 2005, 38, 2544-2546. [CrossRef]

46. Cherian, A.E.; Rose, J.M.; Lobkovsky, E.B.; Coates, G.W. A $C_{2}-$ Symmetric, Living $\alpha$-Diimine Ni(II) Catalyst: Regioblock Copolymers from Propylene. J. Am. Chem. Soc. 2005, 127, 13770-13771. [CrossRef] 
47. Meinhard, D.; Wegner, M.; Kipiani, G.; Hearley, A.; Reuter, P.; Fischer, S.; Marti, O.; Rieger, B. New Nickel(II) Diimine Complexes and the Control of Polyethylene Microstructure by Catalyst Design. J. Am. Chem. Soc. 2007, 129, 9182-9191. [CrossRef] [PubMed]

48. Meinhard, D.; Rieger, B. Novel Unsymmetric $\alpha$-Diimine Nickel(II) Complexes: Suitable Catalysts for Copolymerization Reactions. Chem. Asian J. 2007, 2, 386-392. [CrossRef] [PubMed]

49. Anselment, T.M.J.; Vagin, S.I.; Rieger, B. Activation of Late Transition Metal Catalysts for Olefin Polymerizations and Olefin/CO Copolymerization. Dalton Trans. 2008, 34, 4537-4548. [CrossRef]

50. Popeney, C.S.; Rheingold, A.L.; Guan, Z. Nickel(II) and Palladium(II) Polymerization Catalysts Bearing a Fuorinated Cyclophane Ligand: Stabilization of the Reactive Intermediate. Organometallics 2009, 28, 4452-4463. [CrossRef]

51. Camacho, D.H.; Guan, Z. Designing Late-transition Metal Catalysts for Olefin Insertion Polymerization and Copolymerization Chem. Commun. 2010, 46, 7879-7893. [CrossRef] [PubMed]

52. Okada, T.; Takeuchi, D.; Shishido, A.; Ikeda, T.; Osakada, K. Isomerization Polymerization of 4-Alkylcyclopentane Catalyzed by Pd Complexes: Hydrocarbon Polymers with Isotactic-Type Stereochemistry and Liquid-Crystalline Properties. J. Am. Chem. Soc. 2009, 131, 10852-10853. [CrossRef]

53. Allen, K.E.; Campos, J.; Daugulis, O.; Brookhart, M. Living Polymerization of Ethylene and Copolymerization of Ethylene/Methyl Acrylate Using "Sandwich" Diimine Palladium Catalysts. ACS Catal. 2015, 5, 456-464. [CrossRef]

54. Chen, Z.; Liu, W.; Daugulis, O.; Brookhart, M. Mechanistic Studies of Pd(II)-Catalyzed Copolymerization of Ethylene and Vinylalkoxysilanes: Evidence for a $\beta$-Silyl Elimination Chain Transfer Mechanism. J. Am. Chem. Soc. 2016, 138, 16120-16129. [CrossRef] [PubMed]

55. Takano, S.; Takeuchi, D.; Osakada, K. Olefin Polymerization Catalyzed by Double-Decker Dipalladium Complexes: Low Branched Poly ( $\alpha$-Olefin)s by Selective Insertion of the Monomer Molecules. Chem. Eur. J. 2015, 21, 16209-16218. [CrossRef] [PubMed]

56. Mahmood, Q.; Zeng, Y.; Wang, X.; Sun, Y.; Sun, W.-H. Advancing Polyethylene Properties by Incorporating $\mathrm{NO}_{2} \mathrm{Moiety}$ in 1,2-Bis(arylimino)acenaphthynickel Precatalysts: Synthesis, Characterization and Ethylene Polymerization. Dalton Trans. 2017, 46, 6934-6947. [CrossRef] [PubMed]

57. Belokon, Y.; Moscalenko, M.; Ikonnikov, N.; Yashkina, L.; Antonov, D.; Vorontsov, E.; Rozenberg, V. Asymmetric Trimethylsilylcyanation of Benzaldehyde Catalyzed by (salen)Ti(IV) Complexes Derived from (R)- and/or (S)-4-Hydroxy-5formyl[2.2]paracyclophane and Diamines. Tetrahedron Asymmetry 1997, 8, 3245-3250. [CrossRef]

58. Duan, W.; Ma, Y.; Xia, H.; Liu, X.; Ma, Q.; Sun, J. Design and Synthesis of Planar Chiral Heterocyclic Carbene Precursors Derived from [2.2]Paracyclophane. J. Org. Chem. 2008, 73, 4330-4333. [CrossRef]

59. Ma, Q.; Ma, Y.; Liu, X.; Duan, W.; Qu, B.; Song, C. Planar Chiral Imidazolium Salts Based on [2.2]Paracyclophane in the Asymmetric Rhodium-catalyzed 1,2-Addition of Arylboronic Acids to Aldehydes. Tetrahedron Asymmetry 2010, 21, 292-298. [CrossRef]

60. Göker, V.; Kohl, S.R.; Rominger, F.; Meyer-Eppler, G.; Volbach, L.; Schnakenburg, G.; Lützen, A.; Hashmi, A.S.K. Chiral [2.2]Paracyclophane-Based NAC- and NHC-gold(I) Complexes. J. Organomet. Chem. 2015, 795, 45-52. [CrossRef]

61. Crystal and Calculation Data. Crystal size (mm), $0.25 \times 0.20 \times 0.10 ;$ Measurement $-160{ }^{\circ} \mathrm{C}, \mathrm{MoK} ; \mathrm{Formula}, \mathrm{C}_{46} \mathrm{H}_{40} \mathrm{Br}_{2} \mathrm{Cl}_{2} \mathrm{~N}_{2} \mathrm{Ni}$;

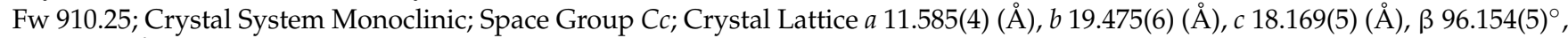
$V 4076(2)\left(\AA^{3}\right) ; Z$ Z $F(000)$ 1848.00; $d_{\text {calcd }} 1.483 \mathrm{~g} \mathrm{~cm}^{-3}$; total Independent Reflections, 8793, Reflections $>2 \sigma$, 6019; Parameters 537; GOF 1.019; $R$ 0.0404, wR 0.0802. Available online: https:/ /www.ccdc.cam.ac.uk/structures/.

62. Janeta, M.; Heidlas, J.X.; Daugulis, O.; Brookhart, M. 2,4,6-Triphenylpyridinium: A Bulky, Highly Electron-Withdrawing Substituent That Enhances Properties of Nickel(II) Ethylene Polymerization Catalysts. Angew. Chem. Int. Ed. 2021, 60, 4566-4569. [CrossRef]

63. Ernst, L.; Wittkowski, L. Diastereomers Composed of Two Planar-Chiral Subunits: Bis([2.2]paracyclophan-4-yl)methane and Analogues. Eur. J. Org. Chem. 1999, 1653-1663. [CrossRef]

64. Reich, H.J.; Cram, D.J. Macro Rings. XXXVIII. Determination of Positions of Substituents in the [2.2]Paracyclophane Nucleus through Nuclear Magnetic Resonance Spectra. J. Am. Chem Soc. 1969, 91, 3534-3543. [CrossRef]

65. Ricci, G.; Ruzziconi, R.; Giorgio, E. Atropisomeric $(R, R)-2,2^{\prime}-\operatorname{Bi}\left([2]\right.$ paracyclo[2](5,8)quinolinophane) and $(R, R)-1,1^{\prime}-$ $\mathrm{Bi}([2]$ paracyclo[2](5,8)isoquinolinophane): Synthesis, Structural Analysis, and Chiropical Properties. J. Org. Chem. 2005, 70, 1011-1018. [CrossRef] [PubMed]

66. Marchand, A.; Maxwell, A.; Mootoo, B.; Pelter, A.; Reid, A. Oxazoline Mediated Routes to a Unique Amino-acid, 4-Amino-13Carboxy[2.2]paracyclophane, of Planar Chirality. Tetrahedron 2000, 56, 7331-7338. [CrossRef]

67. Hitchcock, P.B.; Rowlands, G.J.; Parmer, R. The Synthesis of Enantiomerically Pure 4-Substituted [2.2]Paracyclophane Derivatives by Sulfoxide-metal Exchange. Chem. Commun. 2005, 4219-4221. [CrossRef] [PubMed]

68. Reich, H.J.; Yelm, K.E. Asymmetric Induction in the Oxidation of [2.2]Paracyclophane-Substituted Selenides. Application of Chirality Transfer in the Selenoxide [2,3] Sigmatropic Rearrangement. J. Org. Chem. 1991, 56, 5672-5679. [CrossRef]

69. Dolomanov, O.V.; Bourhis, L.J.; Gildea, R.J.; Howard, J.A.K.; Puschmann, H. OLEX2: A Complete Structure Solution, Refinement and Analysis Program. J. Appl. Cryst. 2009, 42, 339-341. [CrossRef] 